\title{
Homologous ELISA procedure for the determination of penaeid shrimp vitellogenin
}

\author{
Roberto Mendoza $^{(1)}$, Jean-Charles Guillaume ${ }^{(2)}$ and Christian Fauvel ${ }^{(2)}$ \\ (1) Present address: Universidad Autonoma de Nuevo León, Facultad de Ciencias \\ Biologicas. Apartado Postal F-16, Ciudad Universitaria, San Nicolas de Los Garzas, \\ N.L., C.P. $6 \%, 15^{\circ}$, Mexico. \\ (2) IFREMER, Institut français de recherche pour l'exploitation de la mer, \\ B.P. 7o, 29280 Plouzané, France.
}

Reccived July ist, 1992; accepted Fcbruary ist, 1993.

\begin{abstract}
Vitellogenin (VTG) was isolated from the haemolymph of Penaeus vannamei by a three step procedure including ultracentrifugation, gel filtration and ion exchange chromatography. VTG was used to raise polyclonal antibodies that were purificd by ion exchange chromatography. A two step competitive assay was developed in which VTG could be quantitated by its capacity to inhibit the binding of antibody to the VTG previously adsorbed onto a solid phase. Sensitivity from equilibrium and from non-equilibrium assays was 41 and $2.3 \mathrm{ng} / \mathrm{ml}$ respectively. Estimates of within-assay and between-assay variabilities of standard curves were 4.2 and $9.6 \%$ respectively. The inhibition curves for dilutions of haemolymph from vitellogenic lemales, egg yolk extracts and purified vitellin (VTL) were parallel to the standard VTG curve, haemolymph from immature females and males showed no cross-reactivity. The antibodies directed against VTG recognize but partially VTL as shown by displacement curves. Recovery tests were ncar $100 \%$. Thus the procedure was considered to be suitable for the measurement of haemolymphatic VTG. The VTG enzyme-linked immunosorbent assay (ELISA) developed in this study was validated by detecting physiological VTG changes in female shrimps after being fed squid extracts.
\end{abstract}

Mendoza R., J.-C. Guillaume, C. Fauvel, Aquat. Living Resour., 1993, 6, 39-48.

Keywords: Penaeid, vitellogenin, vitellin, immunoassay (ELISA), antibody.

Un test ELISA homologue pour la détermination de la vitellogénine de crevettes pénéidés.

Résumé

La vitellogénine (VTG) de Penaeus vannamei a été purifiée à partir d'hémolymphe par une procédure en trois étapes comprenant l'ultracentrifugation, la filtration sur gel et la chromatographie d'échange d'jons. Un essai compétitif en deux étapes a été développé par lequel la VTG peut être quantifiée en fonction de sa capacité d'inhiber la liaison de l'anticorps à la VTG préalablement adsorbée à une phase solide. La sensibilité pour des essais en équilibre et non-équilibre a été respectivement de 41 et de $2,3 \mathrm{ng} / \mathrm{ml}$. Les coefficients de variation intra-essai et inter-essais ont été respectivement de 4,2 et 9,6\%. Les courbes d'inhibition pour des dilutions de l'hémolymphe de femelles en cours de vitellogenèse, d'homogénats d'ovaire de ces dernières et de vitelline (VTL) purifiée ont été parallèles à la courbe étalon de VTG; en revanche, l'hémolymphe de femelles sexuellement immatures et de mâles n'ont pas montrée de réactivité croisée. Les anticorps dirigés contre la VTG nc reconnaissent que partiellement la VTL comme l'ont montré les courbes de déplacement. Les épreuves de surcharge ont été approximativement de $100 \%$. Ainsi la procédure a été considérée comme adéquate pour mesurer la VTG hémolymphatique. Le test enzymatique immuno-adsorbant (ELISA) développé dans cette étude a été validé physiologiquement en détectant des variations de VTG chez des crevettes femelles nourries avec des extraits de calmar. 
Mots-clés : Pénéidé, vitellogénine, vitelline, immuno-essai (ELISA), anticorps.

\section{INTRODUCTION}

Vitellogenesis is a major metabolic event in the life cycle of female shrimp. It is characterized by vitellin (VTL) oocytic accumulation from the active uptake of a plasma precursor the vitellogenin (VTG) (Meusy, 1988) and/or intraovarian synthesis (Yano, 1988; Rankin et al., 1989; Browdy et al., 1990). This process is regulated by an inhibitory control exerted by the vitellogenic inhibiting hormone (VIH) which is synthesised and released from the organ-X sinus gland complex located in the eyestalk (Jugan and Soyez, 1985; Soyez et al., 1987). Although it has become a regular practice to ablate one eyestalk from shrimp females to induce vitellogenesis, it has been reported that a number of disadvantages arise from this technique such as a lower fecundity and hatching rates as well as shorter periods of viable spawning (Lumare, 1979; Beard and Wickens, 1980, Nascimiento et al., 1991). A more gradual way to induce vitellogenesis is required.

The utilization of squid as a regular component of the feed supplied to the reproductors to favour vitellogenesis has been extensively reported (AQUACOP, 1977; 1979, Chamberlain and Lawrence, 1981; Simon, 1982). However little research has been conducted to elucidate the nature of the stimulatory components.

We describe in the present study the development and validation of an homologous enzyme immunoassay for monitoring penaeid shrimp VTG in order to detect in a sensitive, specific and rapid way the physiological changes induced by the administration of squid extracts.

\section{MATERIALS AND METHODS}

\section{Vitellogenin (VTG) and vitellin (VTL) purification}

VTG was purified from hacmolymph through 3 steps.

Isolation of the lipoprotein fraction by ultracentrifugation on a $\mathrm{KBr}$ density gradient

Haemolymph was adjusted to a density of $1.23 \mathrm{~g} / \mathrm{ml}$ with a $\mathrm{KBr}$ solution $(p=1.33 \mathrm{~g} / \mathrm{ml})$ followed by a $24 \mathrm{~h}$ centrifugation at $120000 \mathrm{~g}$ in a Beckman L5-656 ultracentrifuge equipped with a $50.2 \mathrm{Ti}$ rotor.

\section{Gel filtration}

Lipoproteins were chromatographed on a $2.6 \times 100 \mathrm{~cm}$ column of Sephacryl-300 HR (Pharmacia Fine Chemicals), bed vol. $500 \mathrm{ml}$. The elution was performed with a $0.1 \mathrm{M}$ phosphate buffer $\mathrm{pH} 7.2$ at a llow rate of $1.25 \mathrm{ml} / \mathrm{min}$. The column eluent was monitored at $280 \mathrm{~nm}$.

\section{Ion exchange chromatography}

Pooled fractions from the previous step were applied to a $2.6 \times 8.3 \mathrm{~cm}$ column using DEAE-Spherodex (IBF biotechnology) as support. VTG was eluted by a linear salt gradient from 0 to $0.5 \mathrm{M} \mathrm{KCl}$ in a $50 \mathrm{mM}$ Tris- $\mathrm{HCl} \mathrm{pH} 8$ buffer at a flow rate of $1 \mathrm{ml} / \mathrm{min}$. Filtration through PD-10 (Sephadex G-25, Pharmacia) was carried out after steps 1 and 3 in order to desalt the fractions. Concentration of proteins after step 3 was performed by ultrafiltration using Immersible-CX ultrafilters (Millipore).

After two passages on ion exchange chromatography the VTG was identified as a major single symmetrical pic. This aspect was also confirmed by polyacrylamide gel electrophoresis (PAGE).

VTL was purified using the same procedure but ovaries were first rinsed in a physiological isoosmotic $(950 \mathrm{mOsm} / \mathrm{kg})$ saline and homogenized in a PotterElvejem in cold $50 \mathrm{mM}$ phosphate buffer, phenylmethylsulfonyl fluoride (PMSF) $5 \mathrm{mM}, \mathrm{pH} 7.2$. The homogenate was ultrasonicated and centrifuged at $4000 \mathrm{~g}$ for $15 \mathrm{~min}$ to remove debris and fat material. The supernatant was purified like haemolymph.

\section{Principle of the competitive VTG-ELISA}

Purified VTG is first immobilized in a solid phase, then free VTG contained in samples or standards is added with a diluted antibody. The free VTG will compete with the coated VTG for the binding sites of the diluted antibody thus preventing a certain fraction of this antibody from being immobilized. The amount of antibody bound is measured in a subsequent step by an enzyme labelled second antibody. The enzyme activity detected is inversely related to the VTG concentration in the sample. The assay is calibrated using dilutions of standard VTG as competitor.

\section{Stock solutions}

\section{Coating buffer}

Sodium carbonate 0.05 M, buffer pH 9.6. 


\section{Blocking solution}

Phosphate buffer saline (PBS) $0.01 \mathrm{M}$ phosphate buffer $\mathrm{pH} 7.4,0.15 \mathrm{M} \mathrm{NaCl}, 0.027 \mathrm{M} \mathrm{KCl}$; Tween-20 $0.05 \%$; defatted dry milk $3.5 \%$.

Washing solution

PBS, Tween-20 0.1\%.

Assay buffer

PBS, Tween $0.05 \%$, dcfatted milk $1.25 \%$.

Conjugate buffer

PBS, Tween $0.05 \%$, gelatin $5 \%$.

Enzyme substrate solution

Orthophenylenediamine (OPD) $0.022 \mathrm{M}, \mathrm{H}_{2} \mathrm{O}_{2}$ $0.035 \mathrm{M}$ in phosphate/citrate buffer $\left(\mathrm{Na}_{2} \mathrm{HPO}_{4}\right.$ $2 \mathrm{H}_{2} \mathrm{O} 0.1 \mathrm{M}$, citric acid monohydrated $0.044 \mathrm{M}$ ) $\mathrm{pH}$ 5.5. This solution was prepared extemporaneously.

\section{Substrate stopping solution}

$$
\mathrm{H}_{2} \mathrm{SO}_{4} 4 \mathrm{M}, \mathrm{Na}_{2} \mathrm{SO}_{3} 5 \% \text {. }
$$

\section{General lines for the assay procedure}

\section{Immobilization of VTG}

Nunc Maxisorp F96 microtiter plates were coated with $150 \mu$ l of reference VTG.

\section{Saturation of unbound sites}

Active sites left uncoated by the VTG were blocked by the addition of $200 \mu \mathrm{l}$ of unreactive proteins (blocking solution).

\section{Incubation of samples or reference VTG with anti-VTG antibody}

In this step two modalities were assayed.

- Concurrent incubation, $75 \mu$ l of haemolymph samples (diluted at least 1000 fold) thought to contain VTG or standard VTG were incubated with $75 \mu \mathrm{l}$ of the specific antibody on the sensitized solid phase.

- Sequential incubation. Diluted haemolymph samples were preincubated with specific antibody in Eppendorf tubes followed by a differed transfer of $150 \mu \mathrm{l}$ of the mixture to each coated well, then plates were incubated.

\section{Addition of enzyme-labelled anti $\operatorname{IgG}$}

$150 \mu 1$ of goat anti-rabbit IgG peroxydase conjugate were added to each well and incubated.

\section{Addition of enzyme substrates}

Peroxydase activity was assayed by adding $150 \mu \mathrm{l}$ of substrate solution to each well.
Arrest of the reaction

$50 \mu 1$ of substrate stopping solution were added to each well.

\section{Optical density measurement}

Plates were read on an Argus 300 automated microplate reader (Packard Instruments) linked to a microcomputer for data aquisition and treatment.

During incubations, plates were covered with parafilm, mixed on an orbital shaker and routincly incubated in a humidity chamber.

After the first four steps, plates were washed to remove unbound material. Washing was accomplished by turning the plates upside down and pouring out the contents, then the plates were flushed with the washing solution and finally, they were emptied further by striking them against paper towels and allowed to drain. The procedure was repeated 4 times cach cycle.

The following parameters were estimated in each assay.

- BL: referring to the optical density (O.D.) from the wells devoided of coated VTG, indicating background reading.

- B: corresponding to the O.D. of samples or standards in competition with the coated VTG.

- BO: being the O.D. of wells without free VTG, thus providing maximum binding between coated antigen and specific antibody.

All the determinations for the calibration curve and unknowns were made in duplicate and the mean result was calculated. A number of quality criteria for validation of the assay were taken into account and experiments were so designed to optimize the conditions of every step.

\section{Rocket immunoelectrophoresis (RIE)}

Rocket immunoelectrophoresis was carried out by a modification of the original protocol of Laurell (1966). As a selected application to validate the assay we present partial results of an ongoing study for assessing the effectiveness of squid (Loligo vulgaris) extracts on the triggering of shrimp vitellogenesis.

\section{Preparation of squid extracts}

Initial extracts (lipids and a water-alcohol soluble fraction) were first obtained from a Bligh and Dyer extraction (1959) of whole squid. The rest of the extracts were obtained by further fractionation of the originals, recovering the nonsaponifible fraction of an alkalin hydrolysis in ethylacetate according to the eluotropic series of Makin (1974). The different polarity fractions were included at $1 \mathrm{ppt}$ in a basal semipurified diet containing $44 \%$ protein, $8.6 \%$ lipids, $37.2 \%$ carbohydrates and $10.1 \%$ ash. 


\section{Expression of results and statistical analysis}

VTG immunoassay data were analysed by unweighted least square linear regression after logitlog transformation or by cubic spline interpolation. The suitability of these transformations was tested by residual plot analysis and an $F$ test for linearity after logit-log transformation. Slopes of standard curves were compared by the Student's $t$-test (Sachs, 1984) or an F test according to Dagnelic (1975).

The experimental design to study the effect of squid fractions was a randomized block design, the repetitions (2) along the time of each experimental series were considered as blocks. Comparison of the mean concentrations of different treatments was accomplished by ANOVA and Duncan's new multiple-range test (Steel and Torrie, 1980) and by a $\chi^{2}$ test to assess the difference between proportions of individuals having responded to the fractions (Schwartz, 1984).

\section{RESULTS}

\section{Optimization of the concentrations of reagents}

A maximal absorbance $\mathrm{BO}$ value corresponding to 2 units of (O.D.) was selected in order to have some flexibility while optimizing the assay. Furthermore the reader gives a linear response up to this O.D.

As a first approach optimal concentrations of conjugate and specific antibody were estimated by a dilution of 1:3000. The latter titer was chosen for routine use. In a similar way VTG and specific antibody concentrations were simultaneously determined by chessboard titration (fig. 2). Plates were first coated with log dilutions to estimate the amount needed to reach the O.D. Once the range was identified, fine tuning was performed and a VTG amount of $75 \mathrm{ng} / \mathrm{ml}$ with an antibody dilution of 1:60 000 seemed to give good results, although other combinations of both reagents could have been chosen.

\section{Parallelism}

In order to determine the specificity of the assay for VTG, parallelism studies were conducted ( $f i g .3$ ). Serial dilutions from purified VTL, egg yolk extracts and haemolymph from ripe females showed full parallelism with VTG standard calibration curve $(\mathrm{F}=3.117$ N.S., $p>0.05$ with 3 and 17 d.f.) whereas specificity was further demonstrated by the absence of reaction with immature ovarian homogenates $(t=8.970,9$ d.f. $)$ and haemolymph $(t=10.010,9$ d.f. $)$ as well as with male hacmolymph $(t=10.004,9$ d.f. $)$.

It is noteworthy that when precise doses of vitellin were incubated with coated VTG they generate an inhibition curve, that despitc being parallel, showed only limited immunological potency in the assay (fig. 4).

Additionally the specificity of antibodies was corroborated by immunoenzymatic revelation after sodium dodecylsulfate-polyacrylamide gel electrophoresis (SDS-PAGE) ( $f$ ig. 5).

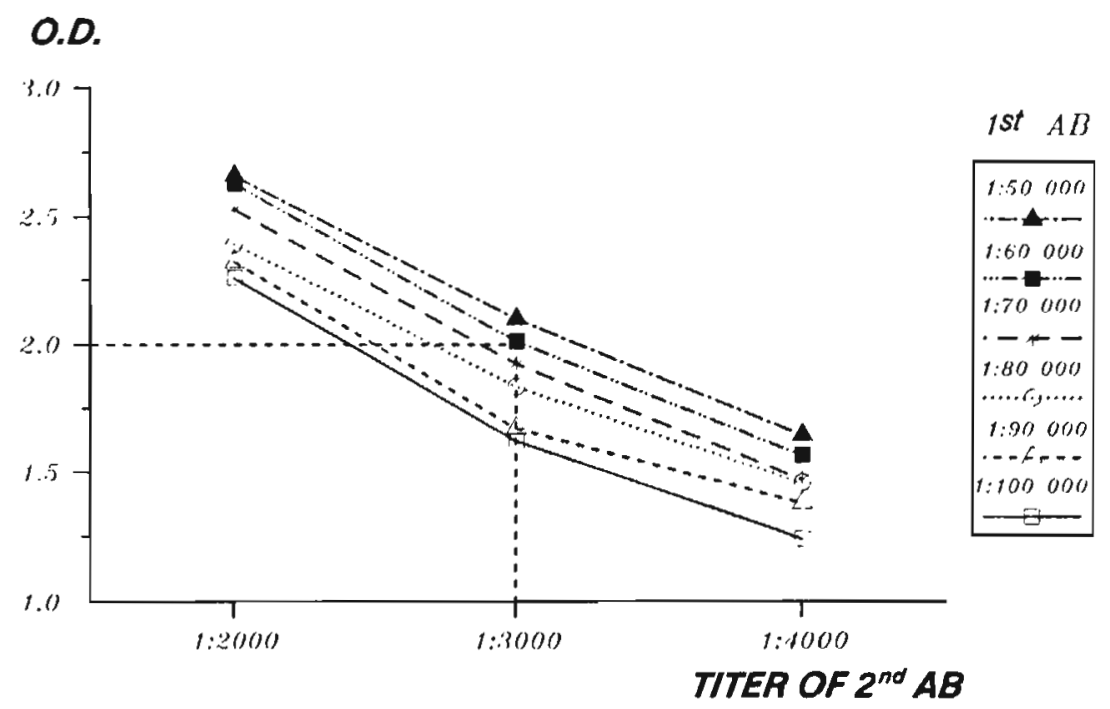

Figure 1. - Optimal concentrations of conjugatc and spccific antibody as determined by chessboard titration.

two dimensional titration ( $f$ ig. 1). Assays indicated that antibody titers ranging from 1:50000 to $1: 70000$ yield a maximal absorbance of 2 O.D. for a conjugate

\section{ELISA-RIE correlation}

In order to test the reliability of the assay a direct comparison was made against RIE by measuring 


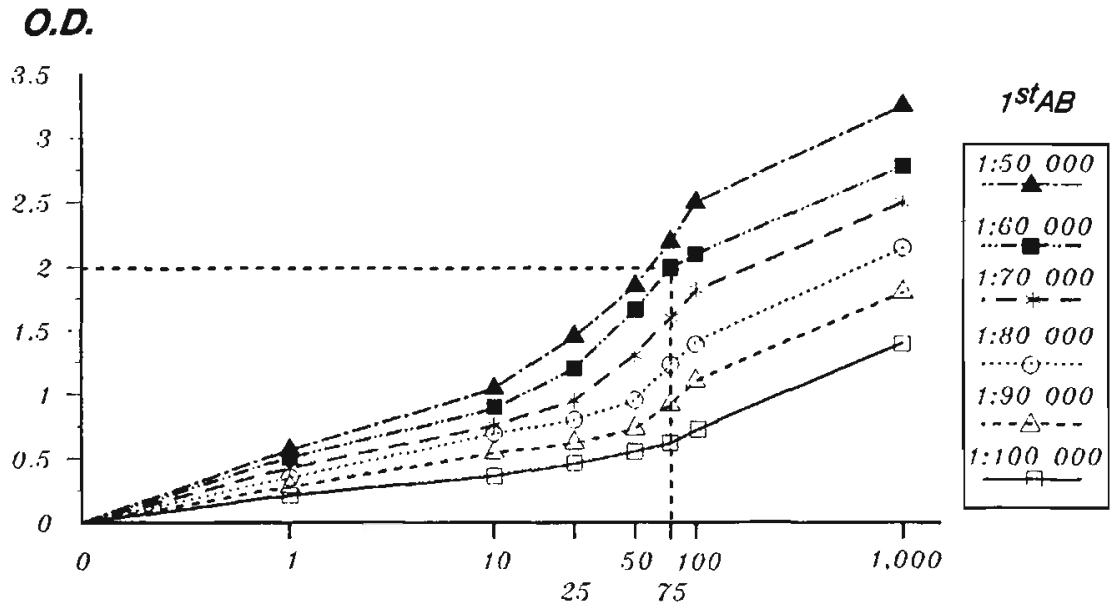

VTG $n g / w e l l$

Figure 2. - Determination of the optimal concentration of vitellogenin (VTG) and first antibody. Wells were coated with serial dilutions of VTG and subsequently incubated, with scrial dilutions of first antibody.

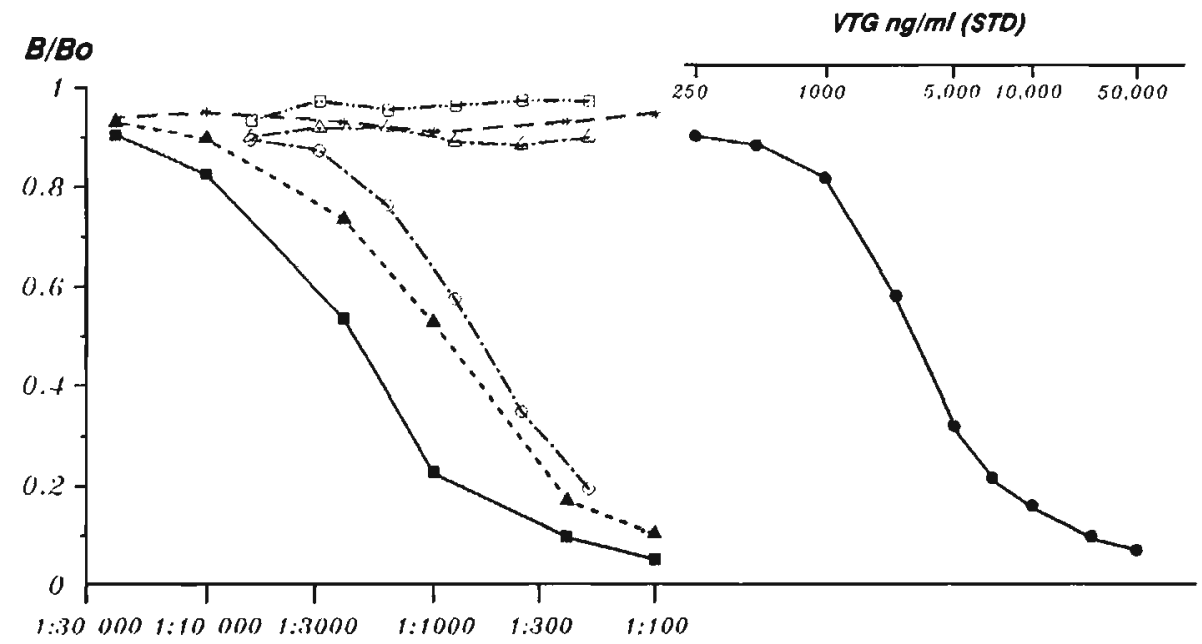

SAMPLE DILUTION

Figure 3. - Inhibition curves from serial dilutions of vitellin (VT) $\boldsymbol{a}$, eggyolk extract $\boldsymbol{\Delta}$, ovarian homogenate of immature females $*$, haemolymph from ripe females $O$, immature females $\triangle$, and males $\square$, compared to reference vitellogenin (VTG) preparation $\bullet$. Each point is the average of duplicate determinations.

some standards and biological samples with both methods. The concentrations $(\mathrm{ng} / \mathrm{ml})$ as determined by ELISA were highly correlated with concentrations estimated by RIE $\left(r^{2}=0.976, n=18\right)$ the slope being very close to the unity $(0.985)$ and an intercept of 498. This value was probably due to the difficulty of measuring rockets at the limit of the assay sensitivity.

\section{Reproductibility}

To determine the inherent variability within a single assay 10 samples (triplicates) containing known quantities of VTG were measured resulting in an average intra-assay coefficient of variation (C.V.) of $4.2 \%$. The variability between assays was calculated by measuring the near $50 \%$ binding of standard curves in 10 separate assays. The C.V. estimated on this basis was $9.6 \%$. Thus a sensitive and reproducible assay has been produced with a wide enough range for practical purposes.

\section{Recovery}

To determine the effect of variation in composition of the incubation media, plasma volumes $(50 \mu \mathrm{l})$ of 


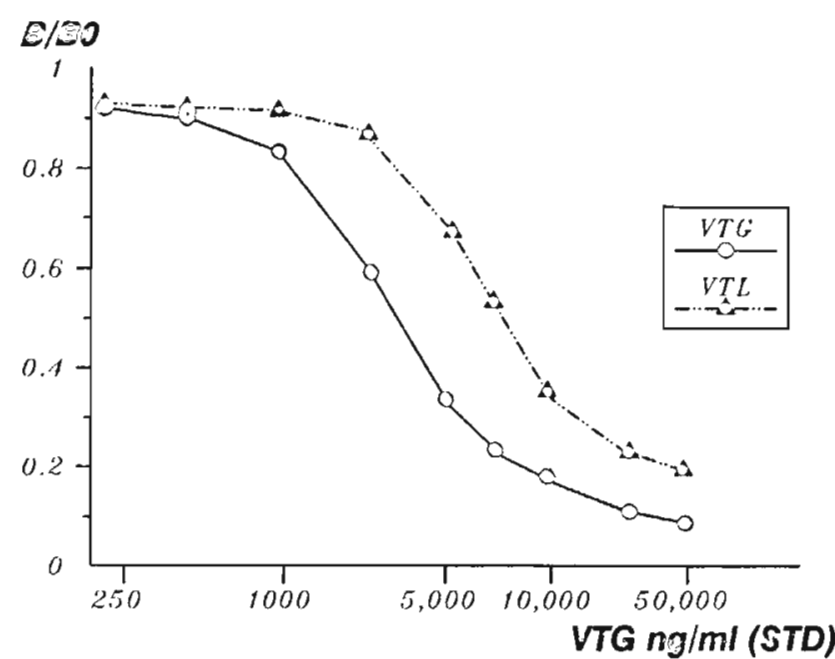

Figure 4. - Dose response inhibition curves for vitellogenin (VTG) and vitcllin (VT).

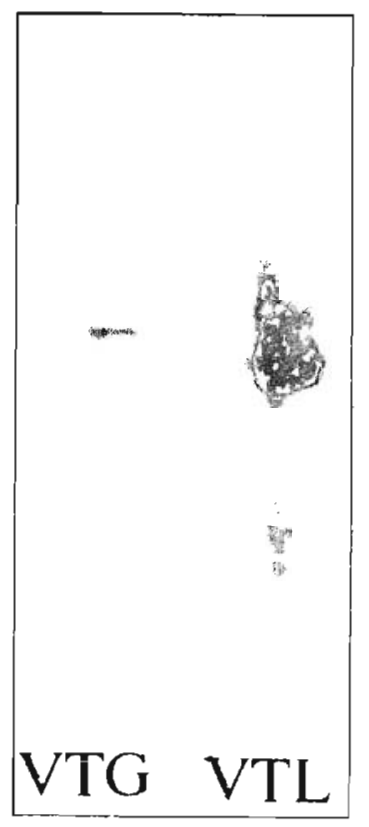

Figure 5. - Immunoblonting palterns of VTG and VTL revealed by $\operatorname{IgG}$ directed against purilied vitellogenin. Revelation was accomplished with a goat-antirabbit IgG peroxydase conjugate, after SDS-PAGE of native molccules and a subsequent transfer 10 a nylon membrane by vacuum blotting.

juvenile females and males were spiked with increasing quantities of VTG (from 500 to $10000 \mathrm{ng}$ ) which resulted in a calculated recovery of 94 and $102 \%$ respectively.

\section{Working range}

Routine calibration curve ranged from 250 to $50000 \mathrm{ng}$, most sensitive and reliable part being between 1000 and $10000 \mathrm{ng} / \mathrm{ml}$.

\section{Statistical parameters}

Mean, slope, intercept and determination coefficients calculated from regressions after linear and curvilinear transformations from 10 separate assays were respectively:

$$
\operatorname{Logit}(\mathrm{B} / \mathrm{BO})=a+b \operatorname{Ln}(\text { Dose })
$$

$$
\begin{aligned}
& a=8.6042 \pm 0.8594 \\
& b=-1.1262 \pm 0.1012 \\
& r^{2}=0.9839 \pm 0.0086 \\
& \mathrm{~B} / \mathrm{BO}=a \operatorname{Ln}(\text { Dose })+b \operatorname{Ln}(\text { Dose })^{2}+c \operatorname{Ln}(\text { Dose })^{3}+d
\end{aligned}
$$

$$
\begin{aligned}
& a=-0.1225 \pm 0.0676 \\
& b=0.0021 \pm 0.0014 \\
& c=0.00009 \pm 9.10^{-7} \\
& d=10.9007 \pm 0.9355 \\
& r^{2}=0.9907 \pm 0.0062
\end{aligned}
$$

\section{Sensitivity}

Sensitivity defined as the smallest amount of VTG that can be distinguished from BO was calculated as twice the S.D. at zero dose. The sequential incubation modality greatly increased the sensitivity of the assay. Allowing antibody to equilibrate with soluble VTG before competition with coated VTG results in a shift of the calibration curve to the left and a steeper curve

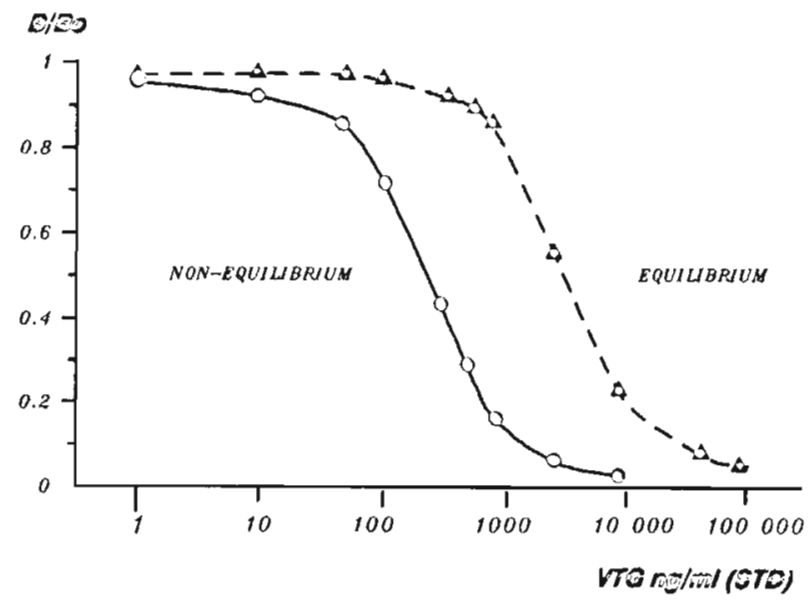

Figure 6. - Comparison of an equilibrium versus a non-equilibrium assay. Reference vitellogenin (VTG) was incubated concurrently with anti-VTG in coated VTG wells (equilibrium) or in separate tubes and subsequently added to VTG coated wells.

(fig. 6). Sensitivity for the equilibrium assay was $41 \mathrm{ng} / \mathrm{ml}$ whereas that of the non-equilibrium assay was only $2.3 \mathrm{ng} / \mathrm{ml}$ and the midpoint sensitivity of the latter $(372.30 \mathrm{ng} / \mathrm{ml})$ was a tenth of that of the former $(3773.65 \mathrm{ng} / \mathrm{ml})$. By changing some of the conditions of the assay (adopting a non-equilibrium 
system, using less coated VTG and with a less diluted conjugate) the sensitivity could be further enhanced up to $565 \mathrm{pg} / \mathrm{ml}$.

\section{Transformation}

The legitimacy of the transformation for both models was tested over a combined calibration curve which integrates data of ten curves. Residual plot analysis showed scatter points with no systematic distribution on either side of the zero value, thus validating the transformation. Transformed data were linear as assessed by the $F$ test: $F=1233.79$ with 1 and 96 d.f.

\section{Time courses and temperature kinetics}

Time course trials and temperature kinetics were investigated in order to improve sensitivity and minimize assay time. Data from time course studies showed that VTG binding was completed after $4 \mathrm{~h}$ at $37^{\circ} \mathrm{C}$ or after $20 \mathrm{~h}$ for all temperatures tested $(4,25$ and $37^{\circ} \mathrm{C}$ ). Optimal saturation time for minimizing background was $1 \mathrm{~h}$.

In the concurrent incubation assay, equilibrium was favoured by increasing incubation times and with high temperatures. We adopted a $2 \mathrm{~h}$ incubation period at $25^{\circ} \mathrm{C}$ to avoid high non specific binding.

Long preincubation times and short in-plate incubations at high temperatures increase sensitivity in such a way that small changes could be better defined. The former is because a short incubation of the mixture (VTG+anti-VTG) with the coated VTG allows

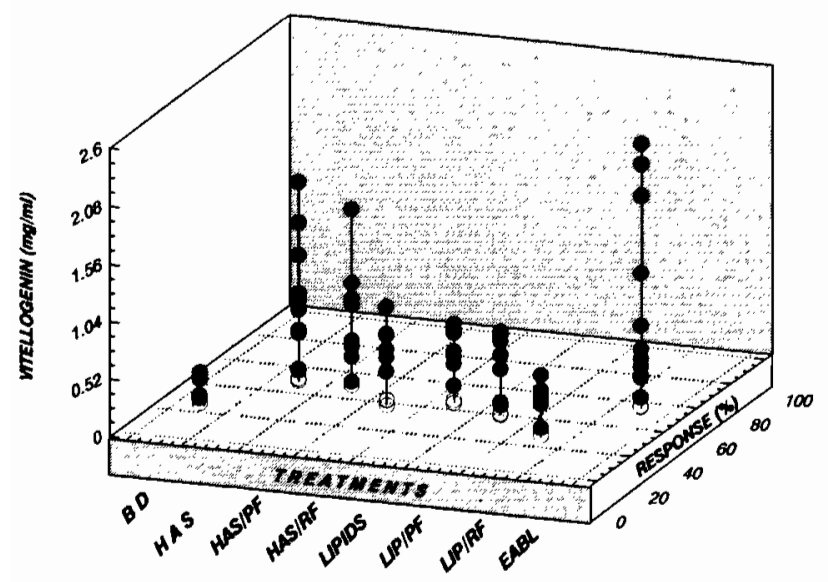

Figure 7. - Effect of squid extracts on shrimp vitellogenesis. Each mark - represents an individual responding to the treatments, marks $O$ are individuals showing only basal level and were not considered in the statistical analysis. Abbreviations: BD basal dict, HAS hydroalcohol soluble fraction, HAS/PF its polar fraction, HAS/RF residual fraction, LIP/PF and LIP/RF polar and residual fraction of lipid fraction, EABL eyestalk ablated females. binding of free antibody before VTG-antibody complexes are disrupted and a new equilibrium is established. The non-equilibrium assay results were similar to those reported in other studies (Farrington and Hymer 1987, Grimaud et al., 1986, Signorella and Hymer, 1984; Salbert et al., 1990).

The binding of the conjugate to the specific antibody reached the 2 O.D. value between 1 and $2 \mathrm{~h}$ at $37^{\circ} \mathrm{C}$.

In other time course experiments, results indicated that it was necessary to let the reaction evolve for at least $30 \mathrm{~min}$ before stopping it and wait during $20 \mathrm{~min}$ before reading the plates. This allowed us to standardize the $\mathrm{BO}$ endpoint for the entire test.

\section{Applications of the competitive ELISA to monitor $P$. vannamei vitellogenesis}

Once the ELISA parameters optimized, this method was physiologically validated by detecting changes in VTG levels correlated with the stimulation vitellogenesis induced by squid fractions ( $f i g .7$ ).

Experimental results reveal that an increase in the VTG level can be induced by squid fractions included in the feed in pubescent females. This is especially the case for the hydroalcohol soluble fraction (HAS) fraction and subfractions in terms of VTG concentrations as denoted by the Duncan's new multiple range test after ANOVA (table 1). Nonetheless it appears likely that a polar component of the lipid extract has also a positive induction potential. In eyestalk ablated females and in intact females receiving the HAS fraction, the mean VTG concentration rose more than five fold relative to the control levels over the course of 15 days.

In terms of the proportion of individuals responding to the experimental treatments no significant changes were appreciated $\left(\chi^{2}=5.79\right.$ (N.S.) $p>0.05$, 7 d.f.).

Table 1. - Results of the ANOVA ( $F=4.01, p<0.05$ with 7 d.f.) and means separation of vitcllogenin concentrations $(\mathrm{ng} / \mathrm{ml})$ registered in female shrimps after being fed with squid extracts (see fig. 7 for abbreviations).

BD LIP/RF Lipids HAS/RF LIP/PF HAS/PF HAS EABL

\begin{tabular}{llllllll}
\hline 0.24 & 0.34 & 0.48 & 0.57 & 0.59 & 0.68 & 0.94 & 0.98
\end{tabular}

\section{DISCUSSION}

The procedure adopted for VTG purification proved successful in maintaining integral antigenicity and was easily applied when scaling up. Utmost care was devoted to this stage because the quality of the ELISA 
relies on this aspect. In fact it is capital for immunisation, calibrating and coating (Ollerich, 1980; Kurstak, 1985).

The specificity of antibodies was established by several lines of evidence. On one hand, the finding of parallel inhibition curves of biological samples which do not deviate significantly suggests the crossreactivity with close-related structural compounds. On the other hand the absence of reaction with samples from pubescent females and males thus proves that the system is suitable for measuring plasmatic VTG.

It was particularly interesting to find out that the displacement of VTG required a greater quantity of VTL due to its partial recognition by the anti-VTG antibody. This confirms the importance of working in a homologous system in which the same antigen is used to generate antibodies, as a standard and as a competitor, as stated by Nicoll (1975) and Maitre et al. (1985). This also evokes the possibility that VTG undergoes some structural changes when entering into the ovary as indicated by Tsumura and Nakagawa (1989), in spite of its qualitative similarity with VTL as reported by Tom et al. (1987), Meusy and Payen (1988), Quinitio et al. (1989) and many others. Recently Tom et al. (1992) mentioned the inconsistence of patterns of VTL immunoprofiles attributable to structural changes taking place in the VTL during oocyte maturation.

Recovery test not only supported specificity but also proved that there was a minimal interference by plasma components in the measurement of immunoreactive VTG.

The reduced values of the coefficient of variation were well within the acceptable limits of the technique and reflected the stability of conditions of the system.

Routine estimations were made with the equilibrium assay because despite its lower sensitivity, it allowed us to determine concentrations over a broader range facilitating in this way the samples dilution and letting us carry out the whole procedure in only $7 \mathrm{~h}$ after overnight coating. If desired, sensitivity can be enhanced by using a non-equilibrium assay with an amplification system like PAP or ABC and modifing some of the conditions of the assay (coating concentration, conjugate dilution, etc.).

A number of different techniques have been established to determine VTG levels in crustaceans including immunodiffusion (Tom et al., 1987; Quinitio et al., 1990), electrophoregram scanning (Byard and Aiken, 1984; Nakagawa et al., 1982), RIE (Yano, 1987; Nelson et al., 1988; Mendoza and Fauvel, 1989) and heterogenous ELISA (Derelle et al., 1986; Quackenbush, 1989). Notwithstanding homologous ELISA properly calibrated appears particularly suitable for the analysis of a large number of samples in a rapid, accurate and inexpensive way.

The sensitivity of our technique compares well with other VTG ELISA's for other species (Dumas et al., 1982, Ma et al., 1984, Derelle et al., 1986, Zou et al., 1988, Nuñez et al., 1989, Cuisset et al., 1991).

The relationship between the increase in plasma VTG and ovarian VTL during the period of ovarian growth has previously been reported (Mendoza and Fauvel, 1989; review in Meusy and Payen, 1988), showing that VTG level from a practical standpoint is a valuable indicator of the reproductive state of female shrimp as well as a good predictor. This was confirmed by our experimental results which revealed that it was possible to induce vitellogenesis in very young females without eyestalk ablation and that a component of squid extracts enabled vitellogenesis induction at the same level as with ablation. The exact nature of this factor remains to be elucidated though it seems likely that a component like the mitosis stimulating factor found in the optical glands and haemolymph of squid (Koueta and BoucaudCamou 1989,1991 ) as well as sex steroids from squid gonads (Carreau and Drowsdowsky, 1977; Blanchier et al., 1986) could be at the origin of this activation.

\footnotetext{
Tom et al., (1992) have noticed changes in the polypeptide pattern of $P$. vannamei VTL during oogenesis a fact which they cxplain as an increased susceptibility of this protein to cnzymatic digestion, being consistent thus with our results.
}

\section{Acknowledgements}

The first author wishes to express his gratitude to Agnès Revol for her technical advice and helpful discussions. This work was supported in part by Mexico.

\section{REFERENCES}

AQUACOP, J. Patrois, J. Barret, J. Mazurié, 1987. Intensive culture of $P$. vanname $i$ and $P$. stylirostris; preliminary results. J. World Aquac. Soc., 18, 1 A.
AQUACOP, 1977. Observations on the maturation and reproduction of penaeid shrimp in captivity in a tropical medium. Aquaculture Workshop; ICES, May 10-13, Brest, France, 4, 157-178.

AQUACOP, 1979. Penaeid reared broodstock: Closing the cycle of Penaeus monodon P. stylirostris and $P$. vannamei. Proc. World Maricul. Soc., 10, 445-452. 
Beard T., J. Wickens, 1980. Breeding of Penaeus monodon Fabricius in laboratory recirculation systems. Aquaculture, 20, 79-89.

Blanchier B., E. Boucaud-Camou, P. Silberzahn, 1986. Comparative study of the sterol composition of the digestive gland and the gonad of Sepia officinalis L. Comp. Biochem. Physiol., 83B, 599-502.

Bligh E., W. Dyer, 1959. A rapid method of total lipid extraction and purification. Can. J. Biochem. Physiol., 37, 911-917.

Bradford M., 1976. A rapid and sensitive method for the quantitation of microgram quantities of protein utilizing the principle of protein-dye binding. Anal. Biochem., 72, 248-254

Browdy C., M. Fainzilber, M. Tom, Y. Loya, E. Lubzens, 1990. Vitcllin synthesis in relation to oogenesis in in vitroincubated ovaries of Penaeus semisulcatus. J. Exp. Zool., 255, 205-215.

Byard E., D. Aiken, 1984. The relationship between molting reproduction, and a hemolymph female-specific protein in the lobster Homarus americanus. Comp. Biochem. Physiol., 77A, 749-757.

Carreau S., M. Drowsdowsky, 1977. The in vitro biosynthesis of steroids by the gonad of the cuttle fish (Sepia officinalis L.). Gen. Comp. Endocrinol., 33, 554-565.

Chamberlain G., A. Lawrence, 1981. Maturation, reproduction and growth of Penaeus vannamei and Penaeus stylirostris fed natural diets. J. World. Maricult. Soc., 12, 209-224.

Cuisset B., C. Pelissero, F. Lc Menn, J. Nuñez, 1991. ELISA for Siberian sturgeon (Acipencer baeri) vitellogenin. In: Acipenser, Williot P., CEMAGREF Publ., 107111.

Dagnelie P., 1975. Théorie et méthodes statistiques, vol. 2. Les presses agronomiques de Gembloux, Belgique, 281291.

Derelle E., J. Grosclaude, J.-J. Meusy, H. Junera, M. Martin, 1986. ELISA titration of vitellogenin and vitellin in the freshwater prawn Macrobrachium rosenbergii, with monoclonal antibody. Comp. Biochem. Physiol., 85B, $1-4$.

Dumas M., J. Bushor, B. Lanzrein, 1982. Development of an enzyme linked immunosorbent assay (ELISA) for measurement of vitellogenin concentrations in cockroaches. Experientia, 38, 874-875.

Farrington M., W. Hymer, 1987. An enzyme immunoassay for rat growth hormone: applications to the study of growth hormone variants. Life Sci., 40, 2479-2488.

Grabar P., C. Williams, 1953. A method permiting the combined study of the electrophoretic and immunochemical properties of a mixture of proteines: application to blood serum. Biochem. Biophys. Acta, 193-194.

Grimaud J.-A., M. Druguet, S. Peyrol, S. Guerret, 1986. Determination of collagen types. In: Methods of enzymatic analysis, vol. 9, Proteins and Peptides, Bergmeyer $\mathbf{H}$. ed., Verlang Chemie Publishers, Weinheim, R.F.A., 195200.

Jugan P., D. Soyez, 1985. Démonstration in vitro de l'inhibition de l'endocytose ovocytaire par un extrait de glandes du sinus chez la crevette Macrobrachium rosenbergii. C.R. Acad. Sci. Paris, 300, Sér. III, 705-709.

Koueta N., E. Boucaud-Camou, 1991. Aspartate trancarbamylase activity, a bioassay for a gonial mitosis stimulating factor from the optic gland of Sepia officinalis $\mathbf{L}$. In: La Seiche (The cuttlefish). 1st Int. Symp., Sepia, Caen, June 1989, Boucaud-Camou E., 271-279.

Koueta N., E. Boucaud-Camou, 1991. In vitro bio-assay for the study of the mitois stimulating factor in the optic gland of Sepia officinalis. Mar. Biol., 108, 419-427.

Kurstak E., 1985. Progress in enzyme immunoassays: production of ragents, experimental design, and interpretation. Bull. W.H.O., 63, 793-811.

Laurell C., 1966. Quantitative estimation of proteins by electrophoresis in agarose gel containing antibodies. Anal. Biochem., 15, 45-52.

Lumare F., 1979. Reproduction of Penaeus kerathurus using eyestalk ablation. Aquaculture, 18, 203-214.

Ma M., P. Newton, G. He, T. Kelly, H. Hsu, E. Masler, A. Borkoveck, 1984. Development of monoclonal antibodies for monitoring Aedes atropapalpus vitellogenins. $J$. Insect. Physiol., 7, 529-536.

Maitre J.-L., C. Le Guellec, S. Derrien, M. Tenniswood, Y. Valotaire, 1985. Measurement of vitellogenin from rainbow trout by rocket immunoelectrophoresis: application to the kinetic analysis of estrogen stimulation in the male. Can. J. Biochem. Cell Biol., 63, 982-987.

Makin H., 1984. Methods of steroid analysis: Group estimation and separation techniques. In: Biochemistry of steroid hormones. Makin H. ed., Blackwell Sci. Publ., Oxford, Eng., 483-485.

Mendoza R., C. Fauvel, 1989. Study of crustacean vitellogenesis by vitellogenin assay: the particular case of a penacid shrimp. Europ. Aquac. Soc. spec. publ., 10, 169170.

Mcusy J.-J., G. Payen, 1988. Female reproduction in Malacostracean Crustacea. Zool. Sci., 5, 217-265.

Nakagawa H., A. Salam, S. Kasahara, 1982. Female-specific lipoprotein level in hemolymph during egg formation in freshwater shrimp. Bull. Jpn. Soc. Sci. Fish., 48, 10731080 .

Nascimiento I., W. Bray., J. Leung, A. Lawrence, 1991. Reproduction of ablated and unablated Penaeus schmitii in captivity using diets consisting of fresh-frozen natural and dried formulated feeds. Aquaculture, 99, 387-398.

Nelson K., B. Heyer, E. Johnson, D. Hedgecock, E. Chang, 1988. Photoperiod-induced changes in hemolymph vitellogenins in female lobster (Homarus americanus). Comp. Biochem. Physiol., 90B, 809-821.

Nicoll C., 1975. Radioimmunoassay and radioreceptor assays for prolactin and growth hormone: a critical appraisal. Am. Zool., 15, 881-903.

Nuñez J., O. Kah, M. Geffard, F. Le Menn, 1989. EnzymeLinked Immunosorbent Assay (ELISA) for sole (Solea vulgaris) vitellogenin. Comp. Biochem. Physiol., 92B, 741746.

Ollerich M., 1980. Enzyme Immunoassays in clinical chemistry: present status and trends. J. Clin. Chem. Clin. Biochem., 18, 197-208. 
Ouchterlony $\ddot{O}$, L. Nilsson, 1986. Immunodiffusion and Immunoelectrophoresis. In: Handbook of experimental immunology, vol. 1: Immunochemistry, Weir D., Blackwell Sci. Publ., Oxford, 32, 1-50.

Peferoen M., R. Huybretch, A. De Loof, 1982. Vacuumblotting: a new simple and efficient transfer of proteins from dodecyl sulfate-polyacrylamide gels to nitrocellulose. FEBS.S lett., 145, 369-372.

Quackenbush I.. S., 1989. Yolk protein production in the marin shrimp Penaeus zannamei. J. Crust. Biol., 9, 509. 516.

Quinitio E., A. Hara, K. Yamauchi, A. Fuji, 1990, Isolation and charactcrization of vitellin from the ovary of Penceus monodon. Invert. Reprod. Der., 17, 221-227.

Rankin S. M., J. K. Bradfield, L. I.. Kelly, 1989. Ovarian protein synthesis in the South-American white shrimp, Penaeus rannamei, during the reproductive cycle. Invert. Reprod. Det., 15, 27-33.

Sachs I.,, 1984. Measures of association, correlation and regression. In: Applied statistics: a handbook of technics. L. Sachs ed., Springer-Verlag, New York, 382-461.

Salbert G., T. Bailache, Y. Zohar, B. Breton, P. Jego, 1990. $A$ rapid and sensitive ELISA for rainbow trout maturational gonadotropin (LG1H II): Validation on biological samples; in vivo and in vitro responses to GnRH. Gen. Comp. Endocrinol., 73, 110-122.

Schwartz D., 1984. Méthodes statistiques à l'usage des médecins et des biologistes. Schwartz D. ed. Flammarion, 85-88.

Signorella A., W. Hymer, 1984. An Enzyme-Linked Immunosorbent Assay for rat prolactin. Anal. Biochem., 135, $372-381$.
Simon C., 1982. Large-scale, commercial application of penacid shrimp maturation technology. J. World Maricult. Soc., 13, 301-312.

Soyez D., J. Van Deijnen, M. Martin, 1987. Isolation and characterization of a vitellogenesis-inhibiting factor from sinus glands of the lobster Homarus americanus. J. Exp. Zool., 244, 479-484.

Steel R., J. Torrie, 1980. Principles and procedures of statistics. A biometrical approach. McGrawhill Book Co., New York, 187-188.

Tom M., M. Goren, M. Ovadia, 1987. Localization of the vitellin and its possible precursors in various organs of Parapenaeus longirostris. Invert. Reprod. Der., 12, 1-2.

Tom M., M. Fingerman, T. Hayes, V. Johnson, B. Kerner, E. Lubzens, 1992. A comparative study of the ovarian proteins from two penacid shrimps, Penaeus semisulcatus de Haan and Penaeus vannamei (Boone). Comp. Bischem. Physiol., 102D, 483-490.

Tsumura S., H. Nakagawa, 1989. Studies, on vitellin accumulation in freshwater shrimp, Palaemon paucidens. $J$. Fac. Appl. Biol. Sci., Hiroshima Univ., 23, 7-14.

Yano I., 1987. Elfect of 17-hydroxy-progesterone on vitellogenin secretion in kuruma prawn Penaeus japonicus. Aquaculture, 61, 49-57.

Yano I., 1988. Induced ovarian maturation of Penacus rannamei by implantation of lobster ganglion. J. World Aquac. Soc., 19, 204-209.

Zou B., J. Stoffolano, J. Nordin, 1988. Subunit composition of vitellin and concentration profiles of vitellogenin, and vitellin in Phormina regina following a protein meal. Comp. Biochem. Physiol., si3, 861-867. 